\title{
ANALISIS RANTAI NILAI (VALUE CHAIN) BAWANG MERAH DI JAWA BARAT
}

\author{
Trisna Insan Noor ${ }^{1}$, Pandi Pardian ${ }^{2}$, Adi Nugraha ${ }^{3}$ \\ ${ }^{1,2,3}$ Dosen di Program Studi Agribisnis, Fakultas Pertanian, Universitas Padjadjaran, Bandung. \\ Alamat email: trisna.insan.noor@unpad.ac.id
}

\begin{abstract}
ABSTRAK
Penelitian ini ditujukan untuk mengevaluasi kinerja rantai nilai bawang merah di Jawa Barat, yang menitik beratkan pada proses penambahan nilai dan aspek keadilan dalam pembagian pendapatan di setiap pelaku yang terlibat di dalam rantai. Peta pelaku, sebaran penambahan nilai, dan pembagian keuntungan dalam rantai nilai bawang merah dijabarkan, dilengkapi oleh formulasi saran kebijakan demi meningkatkan kinerja rantai nilai bawang merah yang dilandasi aspek keadilan. Metode yang diterapkan pada kajian ini adalah pendekatan rantai nilai, yang merupakan suatu kerangka kunci untuk memahami berbagai penggunaan input dan jasa secara bersama yang digunakan untuk menumbuhkan, mengubah, atau menghasilkan suatu produk. Hasil penelitian menunjukkan bahwa sebagian besar nilai tambah dari agribisnis bawang merah dinikmati oleh para pelaku yang terlibat dalam rantai pasokan bawang segar $(52,39 \%-70,23 \%)$, sedangkan sisanya dinikmati oleh pelaku yang berasal dari luar rantai pasokan bawang merah segar $(29,77 \%-47,61 \%)$. Hasil analisis juga menunjukan bahwa penerima nilai tambah terbesar di antara para pelaku adalah petani $(39,87 \%)$, sementara penerima nilai tambah terkecil adalah penebas $(10,62 \%)$. Namun besar kecilnya nilai tambah yang diperoleh setiap pelaku tidak mencerminkan nilai keuntungan yang diterimanya, karena keuntungan lebih dipengaruhi oleh frekuensi transaksi dari setiap pelaku.
\end{abstract}

Kata kunci: bawang merah, rantai nilai, nilai tambah, aspek keadilan, Jawa Barat

\begin{abstract}
This research aims to evaluate the value chain performance of the shallot agribusiness in West Java, in terms of value addition, and equality based profit sharing in each actors involved in the value chain. Map of actors, and value adding processes in each actor were described, and development strategies based on equality aspect were suggested. This study uses value chain analysis approach, which is the key framework in understanding various elements such as inputs and services occurred in the whole process of production and distribution from upstream to downstream. The results show that actors involved in the value chain gained the most value added (52.39\% - 70.23\%) than actors outside the value chain (29.77\% - 47.61\%). Among the involved actors, farmers gained the most added value (39.87\%), while collectors gained the least added value (10.62\%). However, the share does not represent the income generated by each actors. Income is more determined by the frequency of transactions for each actors.
\end{abstract}

Keywords: Shallot, Value Chain, Value Added, Aspect of Equality, West Java

\section{PENDAHULUAN}

Tidak dapat dipungkiri bahwa arus globalisasi dan perkembangan jaman mempunyai pengaruh yang cukup signifikan terhadap sektor pertanian di Indonesia. Salah satu contoh nyata dampak globalisasi adalah penerapan MEA (Masyarakat Ekonomi ASEAN) 2015 yang bisa memberikan peluang dan juga bisa menjadi ancaman, khususnya untuk sektor pertanian di Indonesia. Dilihat dari sisi daya saing, Indonesia memiliki potensi yang sangat besar baik di segi produksi yang didukung oleh kekayaan sumber daya alam dan manusia yang berlimpah, maupun di segi konsumsi yang didukung dengan pasar yang sangat luas. Jawa Barat memiliki potensi yang tidak kalah dari provinsi lain di Indonesia dalam hal keragaman masyarakat dan juga sumber daya alam yang dapat mendukung daya saing, khususnya di bidang pertanian. Salah satu komoditas yang berpotensi besar untuk bersaing di kancah MEA adalah komoditas hortikultura, yang memiliki karakteristik umur tanam yang pendek dan harga jual yang tinggi, 
sehingga aliran uang petani hortikultura cenderung lebih cepat bila dibandingkan dengan komoditas lain.

Bawang merah merupakan komoditas dengan tingkat permintaan yang cukup stabil di Indonesia, khususnya di Jawa Barat, di mana bawang merah tidak hanya dikonsumsi sebagai bahan bumbu masakan, tetapi juga dijadikan bahan mentah produk olahan. Meskipun demikian, komoditas bawang merah masih dihadapkan pada permasalahan fluktuasi harga yang berpengaruh pada tingkat inflasi. BPS mensinyalir bahwa kenaikan harga bawang merah merupakan penyebab terbesar ke dua setelah kenaikan BBM pada bulan Maret 2015. Rendahnya tingkat produktivitas bawang merah dan karakteristik produksi bawang merah yang bergantung pada musim tidak mampu mengimbangi tingkat permintaan yang cenderung konstan. Kondisi ini menyebabkan kesenjangan (gap) antara pasokan (supply) dan permintaan (demand) sehingga menyebabkan fluktuasi harga antar waktu.

Kesenjangan untuk komoditas bawang merah tidak hanya terjadi di tingkat pasokan dan permintaan, tetapi juga terjadi pada pembagian harga, di mana harga di tingkat konsumen terkadang jauh lebih mahal dibandingkan dengan harga di tingkat petani. Ketidak puasan konsumen atas ketidak pastian harga yang berfluktuasi dan kecilnya motivasi para petani yang dipengaruhi oleh ketidak adilan distribusi nilai dalam rantai bawang merah akan menjadi hambatan yang nyata saat produk Jawa Barat harus bersaing dengan produk luar negeri pada era MEA. Oleh karena itu, perlu disusun strategi khusus untuk meningkatkan daya saing komoditas bawang merah, khususnya di provinsi Jawa Barat.

Mewujudkan daya saing komoditas bawang merah di era MEA, memerlukan strategi pengembangan rantai nilai yang mampu menciptakan dan mendistribusikan nilai tambah diantara pelaku yang terlibat dalam agribisnis bawang merah. Penciptaan nilai tambah merupakan untuk mewujudkan efisiensi usaha, sedangkan distribusi nilai tambah adalah proses untuk mewujudkan keadilan berusaha (Bunte, 2006).

Efisiensi dan keadilan merupakan syarat keharusan untuk mewujudkan daya saing karena karakteristik produsen komoditas sayuran dan buah Indonesia memiliki skala usaha yang kecil dan tersebar di berbagai sentra produksi. Pelibatan produsen kecil merupakan salah satu kata kunci selain daya saing dan berkeadilan dalam pengembangan rantai nilai agribisnis dan agroindustri di negara berkembang (Vorley dan Proctor, 2008; Da Silva dan Baker, 2009).

\section{KERANGKA TEORI}

Rantai nilai merupakan suatu kerangka kunci untuk memahami pengunaan berbagai input dan jasa secara bersama yang digunakan untuk menumbuhkan, mengubah atau menghasilkan suatu produk. Selanjutnya, secara fisik produk tersebut bergerak dari produsen ke konsumen dan terjadi proses penciptaan nilai tambah dan peningkatan produktivitas. Selain itu, rantai nilai dapat menjadi suatu titik rujukan untuk perbaikan pelayanan jasa dan lingkungan bisnis (Webber dan Labaste, 2010).

Rantai nilai adalah serangkaian aktifitas dan jasa yang dilakukan untuk mengantarkan suatu produk atau jasa dari mulai proses produksi, konsumsi, hingga barang sudah tidak digunakan lagi (Hellin dan Meijer, 206; Kaplinsky dan Morris, 2000).

Lebih spesifik di dalam sektor pertanian, Amanor-Boadu (2005) berargumen bahwa nilai tambah dalam pertanian terbentuk ketika terjadi perubahan dalam bentuk fisik atau bentuk produk pertanian atau adopsi metode produksi atau proses penanganan yang bertujuan untuk meningkatkan basis konsumen bagi produk tersebut serta mendapatkan porsi yang lebih besar dari pengeluaran pembelanjaan konsumen yang tumbuh untuk produsen. Amanor-Boadu (2005) menambahkan bahwa inisiatif nilai tambah bisnis pada suatu rantai pasokan yang ada terjadi sebagai imbalan atas aktivitas yang dilakukan oleh pelaku usaha inustri hilir pada suatu rantai pasokan. Ukuran imbalan tersebut secara langsung dan proporsional ditujukan untuk memenuhi kepuasan konsumen. Imbalan tersebut dapat berbentuk harga yang tinggi, peningkatan pangsa pasar, dan atau peningkatan akses pasar. Dengan demikian, hal tersebut akan meningkatkan tingkat keuntungan bagi petani.

Analisis rantai nilai dilakukan untuk memperoleh gambaran kinerja agribisnis bawang. Nilai tambah (value added), merupakan hasil dari penerimaan dikurangi biaya input tingkat menengah sebagai indikator finansial yang menunjukkan besaran imbalan kesejahteraan atas korbanan tenaga kerja dan manajemen dalam menghasilkan nilai tambah dalam agribisnis bawang merah, sementara keuntungan (profit) merupakan pendapatan 
bersih (penerimaan dikurangi total biaya) dari hasil usaha yang dilakukan para pelaku agribisnis bawang merah.

Menurut Porter (1985), analisis rantai nilai adalah suatu pendekatan sistem untuk menganalisis perkembangan dari keuntungan persaingan. Porter melihat produsen sebagai sebuah alur/rantai aktivitas dasar yang menambah nilai dari produk/jasa yang dihasilkannya dan pada gilirannya akan memberikan profit. Porter membagi aktivitas dalam rantai nilai menjadi dua, yaitu aktivitas primer dan aktivitas pendukung.

Aktivitas primer dalam rantai nilai merupakan aktivitas dasar produsen untuk memenuhi kepuasan eksternal. Aktivitas primer terdiri dari: Inbound Logistics; Operation; Outbond Logistics; Marketing and Sales; dan Services. Aktivitas pendukung merupakan aktivitas yang ditujukan untuk meningkatkan efisiensi dan efektivitas aktivitas primer. Aktivitas pendukung terdiri dari: Procurement; Technology Development; Human Resource Management; dan Firm Infrastructure

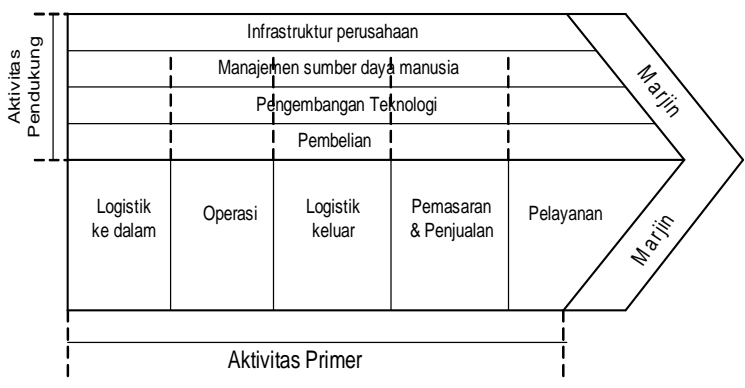

Gambar 1. Konsep Rantai Nilai (Porter, 1985)

Pembagian yang besar pada nilai tambah tidak secara otomatis menyatakan pendapatan yang besar. Walaupun demikian, jika dilihat dari aspek makro ekonomi, nilai tambah adalah parameter yang lebih penting dibandingkan dengan pendapatan dari para pelaku rantai. Pada akhirnya, pertumbuhan yang dihasilkan dari sektor jasa yang terkait juga dihitung dalam pertumbuhan yang memihak petani.

\section{METODE PENELITIAN}

Penelitian dilaksanakan di 5 (lima) Kabupaten sentra produksi bawang merah di Provinsi Jawa Barat yaitu di Kabupaten Cirebon, Bandung, Garut, Majalengka dan Kuningan (Gambar 2). Pemilihan lokasi didasarkan atas hasil produksi bawang merah dari kelima sentra tersebut mendominasi produksi bawang merah Jawa Barat $(98,42 \%)$.
Selanjutnya, dari setiap kabupaten dipilih satu kecamatan yang merupakan sentra produksi bawang merah di kabupaten tersebut, serta juga merupakan pusat distribusi atau para pelaku di kecamatan tersebut berpengaruh terhadap pendistribusian bawang merah yang berasal dari kabupaten tersebut.

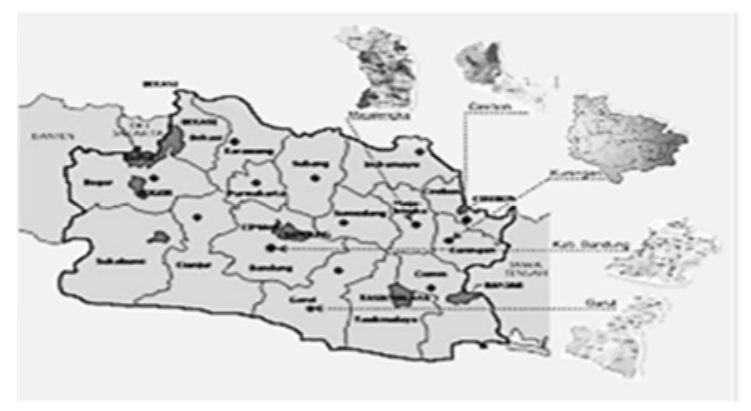

Gambar 2. Sebaran Lokasi Studi Bawang Merah di Provinsi Jawa Barat

Data yang dipergunakan dalam studi ini terdiri dari data primer dan sekunder. Melalui survai, data dikumpulkan dengan mengamati dan melakukan wawancara terstruktur dengan responden pengusaha bandar bawang merah, pedagang pengumpul, petani dan indutri pengolahan bawang merah di masing-masing lokasi studi. Dalam pengumpulan data, akan digunakan kuesioner yang berisi pertanyaanpertanyaan yang akan diajukan kepada setiap kelompok responden. Sementara data sekunder diperoleh dari pencatatan/keterangan dari instansi terkait, seperti Dinas Pertanian, Badan Ketahanan Pangan, BPS, Kecamatan, Desa serta laporan hasil penelitian terdahulu. Untuk melengkapi informasi yang diperlukan juga dilakukan wawancara terhadap Pengurus Dewan Bawang Nasional, Penyuluh Pertanian, dan Tokoh Tani setempat.

Selanjutnya dilakukan penelusuran dengan melakukan pemetaan rantai nilai (value chain mapping) bawang merah dari petani ke pelaku di hilir, dengan titik awal penelusuran dimulai dari bandar besar hingga ke petani pemasoknya serta pelaku di hilirnya baik pedagang di pasar induk atau industri pengolahan. Pemetaan dan penelusuran dilakukan untuk melihat ada tidaknya koordinasi vertikal antara pelaku di hilir dan pelaku di hulu serta besarnya nilai tambah dan pendistribusiannya antar pelaku.

Teknik penarikan sampel di setiap kecamatan dipergunakan teknik dominant less dominant design (Creswell, 1994), yaitu penelitian berdasarkan jumlah sampel usaha sebagai bandar, sesuai dengan hasil penelusuran 
yang menunjukkan posisi strategis bandar dalam rantai pasokan bawang merah di masing-masing lokasi studi. Selanjutnya dari bandar diikuti dengan penelusuran rantai (saluran) dengan melakukan wawancara secara mendalam, hingga ke petani secara sistematik untuk mendapatkan jumlah responden dalam penelitian ini, baik untuk pelaku di hilir, bandar, pedagang dan petani yang dalam pemilihan saat wawancaranya akan dilakukan secara acak sistematik.

Berdasarkan deskripsi rantai nilai yang terbangun antara daerah sentra produksi dengan daerah konsumsi dari hasil wawancara mendalam dengan key informan, kemudian dilakukan penelusuran rantai nilai. Dari para pelaku tersebut kemudian digali informasi, baik kuantitatif maupun kualitatif, mengenai biaya, aktivitas, dan nilai jual dari setiap rantai pada rantai nilai. Selanjutnya, keseluruhan biaya dan nilai tambah pada setiap rantai nilai direkonstruksi dan dianalisis.

\section{HASIL DAN PEMBAHASAN}

\section{Nilai Tambah yang Diterima Pelaku Terhadap Harga Bawang Merah}

Secara umum rantai pelaku pasokan bawang merah di seluruh lokasi kajian yang mencerminkan sebesar 98\% pasokan bawang merah Jawa Barat dapat dikelompokkan kedalam 4 (empat) saluran pemasaran, yaitu :

a) Petani - Bandar Antar daerah

b) Petani - Penebas - Pedagang Pengumpul Pasar Induk Caringin/Pasar Lokal

c) Petani - Bandar Lokal - Pasar Induk Caringin/Pasar Lokal

d) Petani - Pedagang pengumpul - Bandar Antar Daerah

Setiap kabupaten yang dikaji memiliki empat saluran pemasaran tersebut. Khusus untuk saluran Pemasaran "Petani - Penebas Bandar Antar daerah" dan "Petani - Bandar Antar Daerah" banyak dilakukan oleh petani dan pelaku pasar di Kabupaten Cirebon dan Garut. Selanjutnya, analisis rantai nilai bawang merah akan dibagi dalam musim hujan dan musim kemarau. Pembagian ini dilakukan karena ketersediaan dan harga rata-rata antara musim hujan dan kemarau berbeda, demikian juga di sentra produksi utama, pelakunya pun berbeda. Petani lahan kecil lebih banyak melakukan budidaya di musim hujan, terutama di lahan non sawah, sementara pemilik lahan luas dan bandar yang memiliki modal besar, lebih banyak menanam bawang merah di musim hujan. Satuan yang digunakan dalam analisis nilai tambah ini adalah setara dengan 1 kuintal bawang merah segar. Artinya, jumlah material fisik dan bahan baku dihitung dan dikonversi dengan nilai yang setara untuk menghasilkan bawang merah segar sebanyak 1 kuintal.

Pada musim hujan, rata-rata harga bawang merah di tingkat petani di beberapa sentra produksi untuk semua wilayah pada saat penelitian berkisar antara Rp 875.000 sampai Rp 1.000.000 per kuintal. Harga terendah terjadi di Kabupaten Bandung dan Garut pada musim hujan, sedangkan harga tertinggi di Kabupaten Bandung. Sementara di tingkat bandar antar daerah (bandar besar), harga bawang merah berkisar antara Rp 1.275.000 sampai Rp 1.800.000 per kuintal. Harga tertinggi terjadi di Kabupaten Majalengka, sedangkan harga terendah di Kabupaten Cirebon dan Garut.

Pada musim kemarau, rata-rata harga bawang merah di tingkat petani adalah antara Rp 775.000 sampai Rp 850.000 per kuintal. Harga tertinggi terjadi di Kabupaten Kuningan, sedangkan harga terendah di Kabupaten Cirebon dan Garut. Sementara di tingkat bandar antar daerah (bandar besar), harga bawang merah berkisar antara Rp 1.100.000 sampai Rp 1.800 .000 per kuintal. Harga tertinggi terjadi di Kabupaten Majalengka, sedangkan harga terendah di Bandung.

Perbedaan harga antar wilayah dan antar musim, menunjukkan bahwa harga di sentra produksi utama serta relatif jauh dari tujuan pasar akan lebih rendah dibandingkan dengan wilayah lainnya. Selain itu harga rata-rata bawang merah pada musim kemarau lebih rendah dibandingkan musim hujan, namun biaya produksinya pun lebih rendah disertai dengan resiko cepat busuk pada musim kemarau lebih kecil, sehingga keuntungan pada musim kemarau lebih tinggi dibandingkan musim hujan.

Sebagian besar nilai tambah dari agribisnis bawang merah, di 5 kabupaten yang dikaji, dinikmati oleh para pelaku terlibat dalam rantai pasokan bawang merah segar $(52,39 \%$ $70,23 \%$ ), sedangkan sisanya dinikmati oleh pelaku yang berasal dari luar rantai pasokan bawang merah segar $(29,77 \%-47,61 \%)$ (Gambar 3). Nilai tambah terbesar diperoleh oleh para pelaku yang memasarkan produk bawang merahnya melalui pedagang pengumpul pada musim kemarau. Sementara nilai tambah pelaku terkecil diperoleh oleh 
petani yang memasarkan produknya langsung ke bandar antar daerah pada musim hujan.

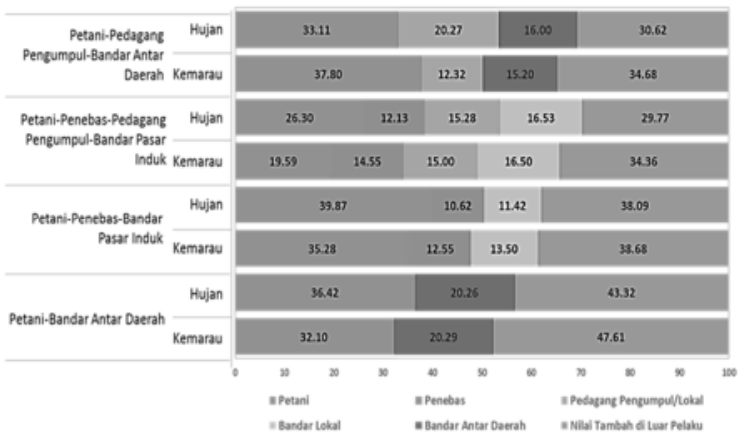

Gambar 3. Nilai Tambah yang Diterima Pelaku Terhadap Harga Bawang Merah

Hasil analisis menunjukkan bahwa penerima nilai tambah terbesar di antara para pelaku yang terlibat dalam agribisnis bawang merah adalah petani, yaitu 39,87\% dari harga jual bawang merah segar ke pasar induk. Sementara itu penerima nilai tambah terkecil adalah penebas yaitu sebesar $10,62 \%$, tidak jauh beda dengan pada umumnya rata-rata nilai tambah para pedangang, baik pedagang pengumpul, bandar lokal maupun bandar antar daerah. Penjelasan lebih terperinci mengenai struktur pembentuk nilai tambah pada setiap pelaku rantai pasokan bawang merah segar dipaparkan pada sub-bab berikut.

\section{Struktur Nilai Tambah Setiap Pelaku dalam Agroindustri Perberasan}

\section{Petani}

Nilai tambah petani terdiri atas nilai tambah dari tenaga kerja, baik tenaga kerja budidaya maupuan tenaga kerja panen dan pascapanen, penyusutan alat dan keuntungan yang diperoleh petani. Analilis nilai tambah secara terpisah per pelaku menunjukkan bahwa nilai tambah yang diterima petani sebesar 39,19\%$55,59 \%$, sementara nilai tambah sisanya antara $44,41 \%-60,81 \%$ untuk di luar petani.

Nilai tambah petani terkecil $(39,19 \%)$ diperoleh oleh petani yang memasarkan bawang merahnya melalui penebas - pedagang pengumpul - Bandar Pasar Induk pada musim kemarau. Hal ini terjadi disebabkan oleh panjangnya rantai tata niaga dan biaya produksinya lebih tinggi terutama untuk penggunaan pestisida dan pengadaan air untuk menyiram, walaupun harga pada musim kemarau lebih tinggi dibandingkan musim hujan. Oleh karena itu, pada musim hujan, nilai tambah yang diperoleh oleh pelaku di luar petani menjadi lebih tinggi. Sementara nilai tambah petani terbesar $(55,59 \%)$ diperoleh oleh petani yang memasarkan bawang merahnya melalui pedagang pengumpul - bandar antar daerah pada musim kemarau, karena sedikit ada pelaku lain yang teribat, atau dengan kata lain terjadi pada rantai pemasaran yang relatif pendek dibandingkan rantai pemasaran lainnya.

Dari total nilai tambah yang diperoleh petani tersebut, keuntungan merupakan nilai tambah terbesar diikuti oleh tenaga kerja yang diperoleh petani. Rata-rata nilai tambah dalam bentuk keuntungan adalah sebesar 29,23\%, sedangkan rata-rata nilai tambah tenaga kerja yang diperoleh petani adalah sebesar 19,42\%.

Nilai tenaga kerja terbesar sebesar 21,80\% diperoleh oleh petani yang memasarkan bawang merahnya melalui pedagang pengumpul dan selanjutnya ke bandar antar daerah pada musim hujan. Sementara nilai tambah tenaga kerja terkecil $(10,42 \%)$ diperoleh petani yang memasarkan hasil produksinya langsung ke bandar antar daerah di musim kemarau.

Nilai tambah berupa keuntungan petani terbesar $(35,68 \%)$ dan terkecil $(17,70 \%)$ diperoleh oleh petani yang memasarkan bawangnya melalui penebas-pengumpul-bandar pasar induk. Keuntungan terbesar diperoleh pada musim hujan sedangkan keuntungan terkecil pada musim kemarau. Hal tersebut juga menunjukkan bahwa petani bawang merah di Jawa Barat berbeda dengan petani di Jawa tengah dan Jawa Timur. Kuntungan petani bawang merah di Jawa Barat pada musim hujan lebih besar dibandingkan pada musim kemarau, sedangkan petani bawang merah di Jawa Tengah dan Jawa Timur sebaliknya.

Proporsi nilai tambah terhadap harga bawang merah untuk analisis di tingkat petani yang berkisar antara 39,19\%-55,59\% menunjukkan besarnya proporsi imbalan kesejahteraan yang diterima secara langsung oleh rumah tangga petani bawang merah. Keuntungan petani menjadi pendapatan bagi 


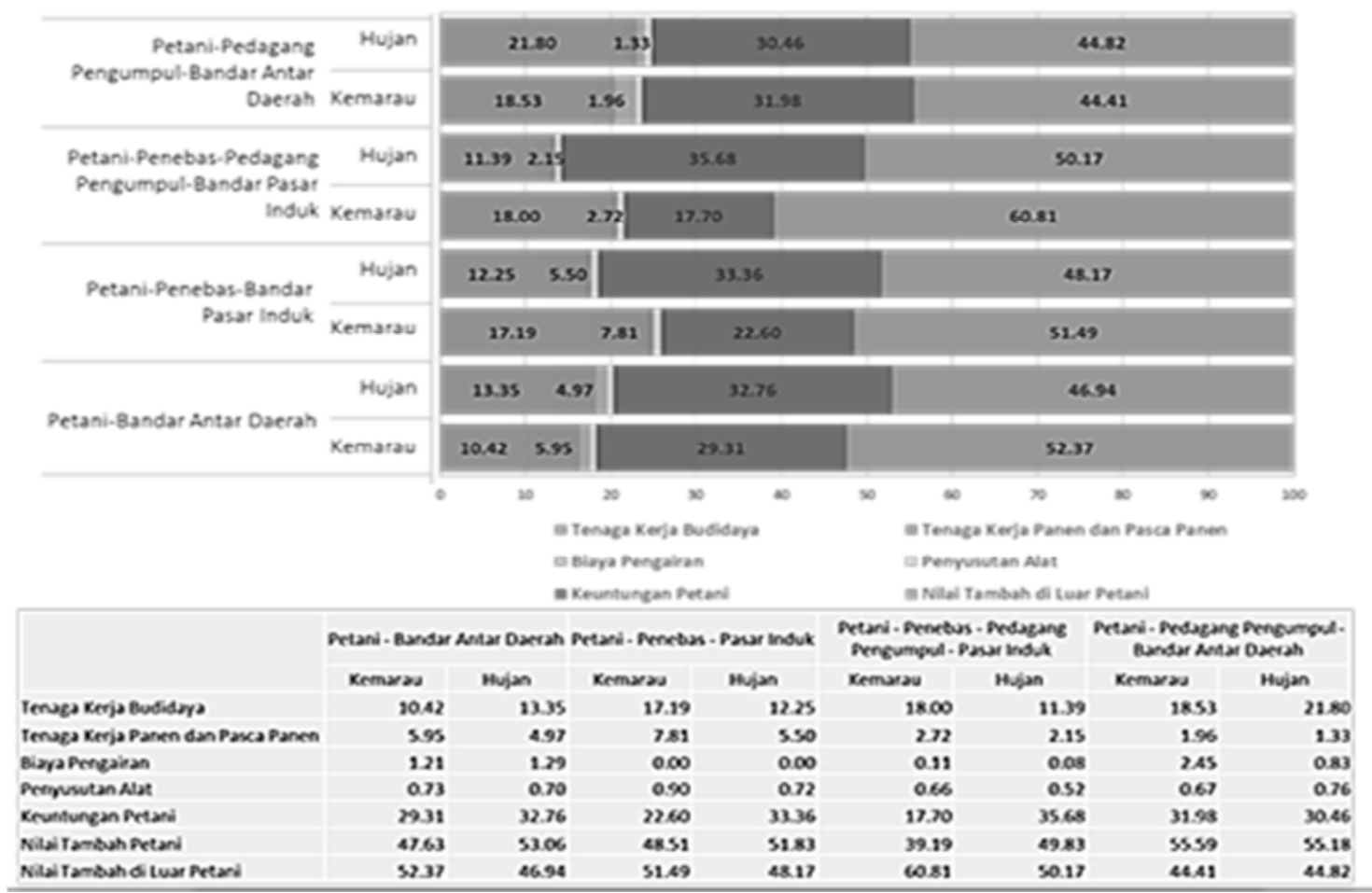

Gambar 4. Struktur Nilai Tambah di Tingkat Petani (dalam \%)

rumah tangga petani. Sementara tenaga kerja menjadi pendapatan yang diterima oleh rumah tangga petani buruh yang menjadi buruh tani dalam bentuk upah. Upah yang diterima oleh tenaga kerja buruh tani merupakan bentuk transfer nilai dalam interaksi antara petani berlahan luas dan petani berlahan sempit atau bahkan tuna lahan. Petani berlahan luas mendapatkan jasa tenaga kerja, sementara petani buruh mendapatkan imbalan dari bekerja. Namun, apabila tenaga kerja yang terlibat sepenuhnya menggunakan tenaga kerja dalam keluarga, maka nilai tambah tenaga kerja tersebut menjadi pendapatan rumah tangga petani itu sendiri.

Aktivitas nilai tambah yang berada di luar petani adalah penggunaan input produksi atau sarana produksi pertanian. Input produksi seperti benih, pupuk dan pestisida diproduksi bukan oleh petani, sehingga imbalan dari pembuatan input produksi tidak dinikmati petani bawang merah, melainkan pihak lain yaitu industri produk terkait, distributor atau pedagang dan sebagainya yang terlibat. Pada umumnya pelakunya berada di luar perdesaan.
Dari nilai tambah di luar petani tersebut, nilai tambah terbesar yang dinikmati pihak lain adalah nilai tambah yang berasal dari benih bawang yaitu antara 23,9\%-28,5\% dari total nilai tambah atau sebesar 50,4\%-54,7\% dari total nilai tambah yang diperoleh pihak lain di luat petani, jika seluruh benih yang dibutuhkan berasal dari pembelian ke pihak lain. Besarnya nilai tambah petani tersebut disebabkan, biaya produksi untuk benih merupakan biaya produksi terbesar yaitu sebesar 35,8\%-38,3\% dari total biaya produksi dalam usahatani bawang merah.

Oleh karena itu, sebagian besar petani melakukan pengadaan benih sendiri, dengan menyisihkannya dari hasil panen bawang merah sebelumnya. Dengan demikian nilai tambah yang berasal dari benih tersebut dapat dinikmati oleh petani itu sendiri, dengan rata-rata penambahan nilai tambah petani sebesar $23,9 \%$ pada musim hujan dan 28,46\% pada musim kemarau. Dengan kata lain, jika benih berasal dari petani sendiri, maka nilai tambah yang diperoleh petani menjadi naik sebesar 59,7\% dari 47,7\% menjadi 76,2\% pada musim kemarau dan naik sebesar $45,7 \%$ dari $52,5 \%$ menjadi 76,5\% (Gambar 5). 


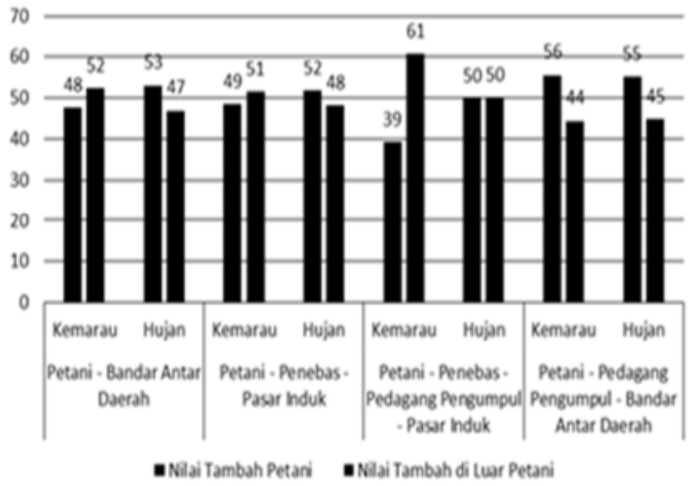

a. Jika Benih Asal Beli

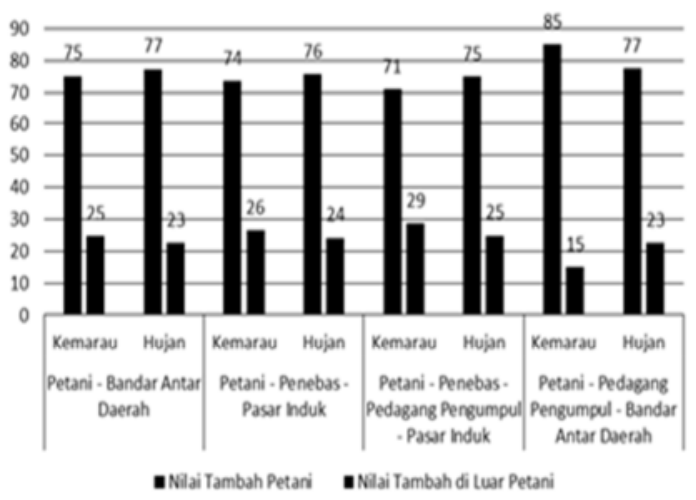

b. Jika Benih Asal Sendiri

Gambar 5. Perbedaan Nilai Tambah yang Diperoleh Petani Jika Bibit Membeli dan Asal Sendiri.

\section{Penebas}

Penebas melakukan aktivitas usahanya dengan membeli bawang merah, baik dengan cara ijon atau membeli sebelum waktunya panen biasanya 3-4 minggu sebelum waktu panen, maupun dengan membeli pada saat panen. Cara pembeliannya dilakukan dengan memborong hasil panen dalam satuan luas sesuai yang diusahakan petani. Selanjutnya, bawang merah hasil tebasannya tersebut dijual ke pedagang pengumpul atau bandar besar (bandar pasar induk atau bandar antar daerah).

Adapun cara pembayarannya tergantung kepada tingkat permintaan bandar. Namun, pada umumnya, penebas akan memberikan uang panjar terlebih dahulu kepada petani, yang jumlahnya ditentukan berdasarkan kesepakatan bersama petani dan sisanya dibayarkan kemudian sesuai yang disepakati. Dalam aspek permodalannya, di Cirebon, Kuningan dan Majalengka adakalanya pada musim kemarau dimana banyak terjadi penanaman bawang merah dibandingkan musim hujan, para penebas tersebut sudah mendapatkan uang panjar terlebih dahulu dari bandar antar daerah.
Nilai tambah penebas terdiri dari nilai tambah dari tenaga kerja (baik tenaga kerja panen, angkut, muat dan bongkar) dan dari keuntungan yang diperoleh penebas dari hasil tebasan. Hasil analisis nilai tambah di tingkat penebas menunjukkan bahwa nilai tambah yang diterima penebas sebesar 87,31\%-92,00\%, sementara nilai tambah sisanya sebesar $8,00 \%$ 16,69 untuk di luar penebas. Sebagian besar nilai tambah yang diperoleh penebas merupakan keuntungan yaitu 69,35\%-77,33\%, sementara sebagian kecil lainnya berasal dari tenaga kerja muat dan bongkar (Gambar 6).

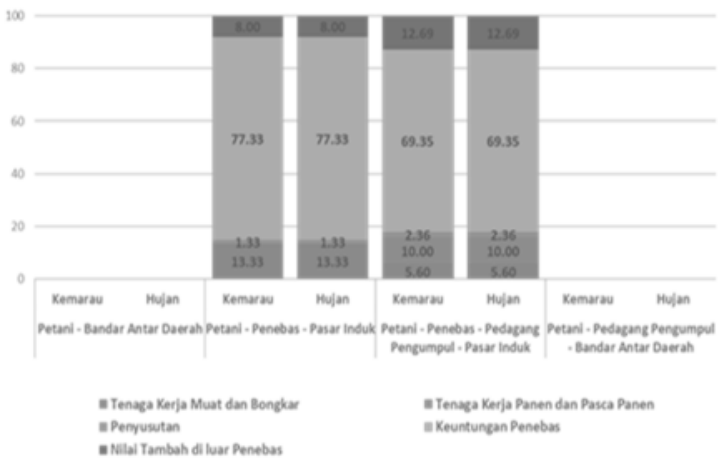

Gambar 6. Struktur Nilai Tambah Ditingkat Penebas

Berdasarkan aktifitas usahanya, nilai tambah yang ada di penebas adalah tenaga kerja panen dan pasca panen serta tenaga kerja untuk muat dan bongkar bawang ke/dari kendaraan. Proporsi kedua aktifitas tersebut jauh di bawah proporsi keuntungan yang dinikmati para penebas. perbedaan imbalan tenaga kerja panen dan pasca panen serta tenaga kerja muat dan bongkar tersebut dinikmati oleh tenaga kerja yang bekerja kepada penebas. Proporsi nilai tambah yang diperoleh penebas ternyata tidak ada perbedaan antar musim, namun berbeda tergantung kepada panjang pendeknya rantai pemasaran.

\section{Pedagang Pengumpul}

Pedagang pengumpul menjalankan usahanya dengan cara mengumpulkan dan membeli bawang merah sehar dari petani di berbagai lokasi untuk kemudian dijual kepada bandar antar daerah (bandar besar). Aktifitas yang dilakukan oleh pedagang pengumpul adalah mengangkut bawang berah dari petani ke bandar antar daerah, baik yang dikeringkan terlebih dahulu maupun langsung apa adanya. Dengan demikian, pedagang pengumpul sebagaimana halnya penebas, merupakan penghubung antara petani dengan bandar 
Besarnya nilai tambah pedagang pengumpul dari aktivitas jual beli bawang merahnya adalah $77,00 \%$ - 91,67\% dari harga bawang merah yang dijual ke bandar besar, baik pada musim hujan maupun musim kemarau (Gambar 7). Sebagian besar nilai tambah yang diperoleh pedagang merupakan keuntungan $(64,50 \%$ - 83,50\%), sementara sebagian kecil lainnya berasal dari tenaga kerja muat-bongkar, penyusutan karung dan nilai tambah yang berasal dari luar pedagang bawang merah $(8,30 \%-23 \%)$.

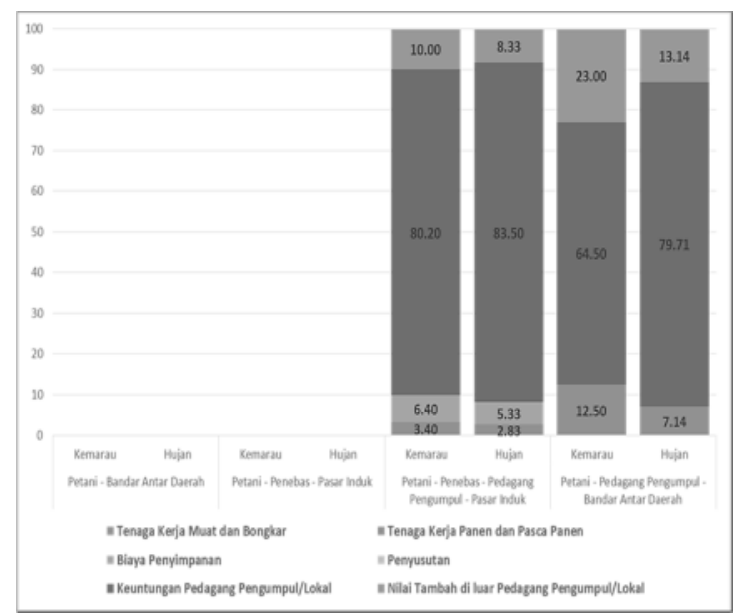

Gambar 7. Struktur Nilai Tambah Tingkat Pedagang Pengumpul

\section{Bandar Lokal}

Bandar Pasar Induk pada umumnya adalah pedagang (bandar besar) yang yang memasarkan produknya ke Pasar Induk Caringin. Bandar pasar induk mempunyai peran dan beraktivitas sebagaimana pedagang pengumpul hanya mempunyai skala yang lebih luas. Jadi bandar menjalankan usahanya dengan cara mengumpulkan dan membeli bawang merah sehar dari petani di berbagai lokasi untuk kemudian dijual kepada pedagang di pasar induk. Aktifitas yang dilakukan oleh bandar pasar induk adalah mengangkut bawang berah dari penebas atau pedagang pengumpul dibawa ke gudangnya untuk dipasarkan langsung ke pedagang pasar induk Caringin, baik yang dikeringkan terlebih dahulu maupun langsung apa adanya.

Adakalanya, bawang tdak dibawa ke gudang dulu tapi langsung diantar ke pasar induk, tergantung dari tinggi rendahnya tingkat permintaan dari pasar induk. Besarnya nilai tambah bandar lokal dari aktivitas jual beli bawang merahnya sama untuk antar musim, yaitu sekitar 99\% dari harga bawang merah yang dijual ke pedagang di pasar induk Caringin. Sebagian besar nilai tambah yang diperoleh pedagang merupakan keuntungan, yaitu $97 \%$ baik pada musim hujan maupun musim kemarau. Sementara sebagian kecil lainnya berasal dari tenaga kerja muat-bongkar, biaya penyimpanan, penyusutan karung dan nilai tambah yang berasal dari luar bandar lokal (Gambar 8).

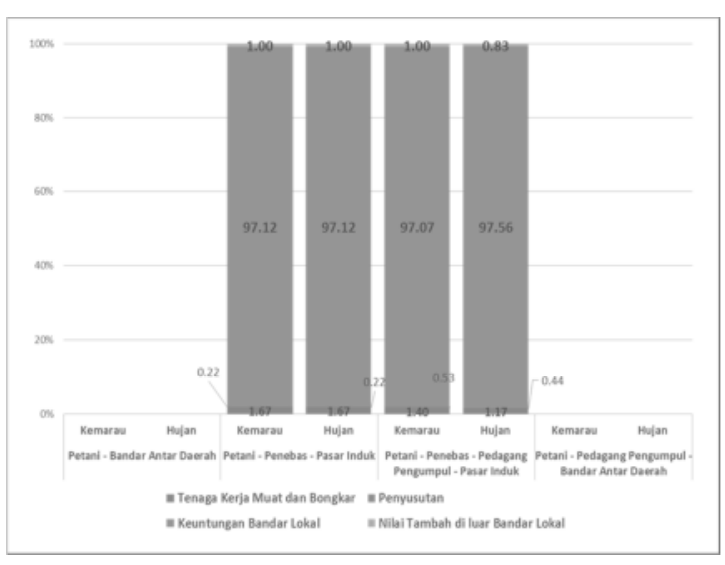

Gambar 8. Struktur Nilai Tambah Tingkat Bandar Lokal

\section{Bandar Antar Daerah}

Bandar antar daerah adalah pedagang yang memasarkan sebagian besar bawang merahnya untuk perdagangan antar Provinsi/ antar pulau. Bandar antar daerah mempunyai peran dan beraktivitas sebagaimana bandar lokal hanya mempunyai volume pemasaran yang jauh lebih besar dan jangkauan pasar yang lebih luas bahkan ke seluruh wilayah Indonesia. Bandar antar daerah menjalankan usahanya dengan cara mengumpulkan dan membeli bawang merah segar dari petani dan pedagang pengumpul dari berbagai lokasi, bahkan bisa diperoleh dari beda Provinsi untuk kemudian dijual ke pedagang di pasar induk Jabodetabek, Bandung hingga pedagang di kota-kota besar di Pulau Sumatera dan Kalimantan. Aktifitas yang dilakukan bandar antar daerah ada yang mengangkut bawang merah dari petani ke gudang miliknya (untuk dikeringkan) dan dipasarkan, namun ada juga bandar antar daerah yang bawang merah segarnya tidak dibawa ke gudang dulu tapi langsung dari sentra produksi pemasoknya langsung diantar ke tujuan pasar, tergantung dari tinggi rendahnya tingkat permintaan dari kota tujuan pasarnya.

Besarnya nilai tambah bandar antar daerah dari aktivitas jual beli bawang merahnya relatif sama untuk antar musim, namun berbeda 
tergantung panjang pendeknya rantai pemasaran. Nilai tambah bandar antar daerah terbesar untuk rantai pemasaran yang langsung membeli dari melalui pedagang pengumpul yaitu berkisar antara 95\% - 96\%, sementara yang langsung dari petani sebesar yang secara rerata lebih besar dibandingkan pada musim hujan yang berkisar antara $62,22 \%-74,58 \%$ dari harga bawang merah yang dipasarkannya (Gambar 9).

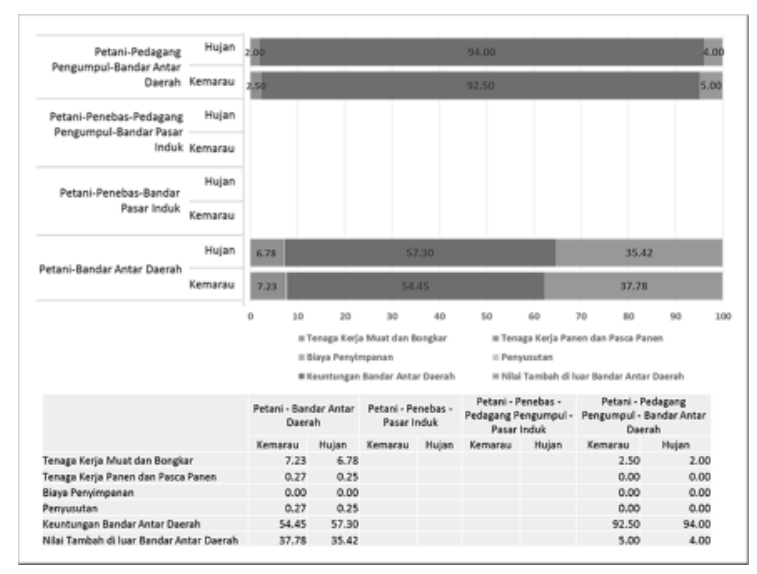

Gambar 9. Struktur Nilai Tambah Tingkat Bandar Antar Daerah

Sebagian besar nilai tambah yang diperoleh pedagang merupakan keuntungan, yaitu berkisar antara $54,45 \%-57,30 \%$ yang membeli dari langsung dari petani dan antara 92,59\% - 94,00\% yang membeli melalui pedagang pengumpul. Sementara sebagian kecil lainnya berasal dari tenaga kerja muat-bongkar, biaya panen, biaya penyimpanan, penyusutan karung dan nilai tambah yang berasal dari luar bandar antar daerah. Perbedaan nilai tambah dan keuntungan tersebut dikarenakan jika membeli dari pedagang pengumpul, bandar antar daerah tidak perlu lagi mengeluarkan biaya transportasi untuk pengangkutan dan biaya lainnya dalam pengadaan karena menjadi beban dari pedagang pengumpul. Sementara jika membeli dari petani, maka biaya bongkar muat, transportasi dan sebagainya menjadi beban bandar antar daerah. Keuntungan bandar lainnya dari membelu dari pedagang pengumpul adalah mendapatkan pengadaan bawang merah dengan kuantitas yang lebih besar dibanding membeli langsung ke petani.

\section{Keuntungan per Pelaku Terhadap Keuntungan Total Pelaku Rantai Pasokan Bawang Merah}

Gambar 10 merupakan perbandingan antara keuntungan yang diperoleh setiap pelaku dengan total keuntungan pada setiap rantai pasokan bawang merah di lokasi kajian. Di tingkat petani, besarnya keuntungan tidak dipengaruhi oleh musim namun ditentukan oleh pilihan pasar. Hal itu terlihat pada rantai pemasaran "petani-pedagang pengumpulbandar antar daerah", proporsi keuntungan terbesar diraih petani pada musim kemarau, sementara pada tiga rantai pemasaran lainnya proporsi keuntungan terbesar diperoleh pada musim hujan. Sedangkan untuk tingkat pedagang, baik penebas, pedagang pengumpul, bandar lokal dan bandar antar daerah pada umumnya keuntungan terbesar diperoleh pada musim kemarau.

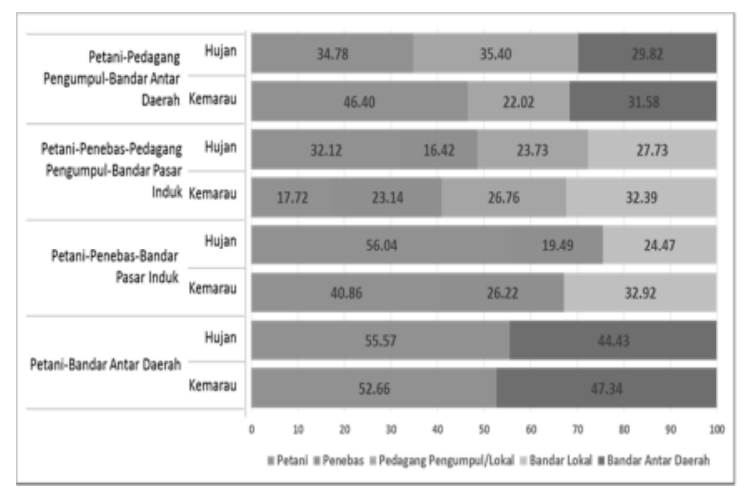

Gambar 10. Keuntungan Pelaku Terhadap Total Keuntungan Pelaku Rantai Pasokan Bawang Merah

Petani memperoleh proporsi keuntungan yang paling besar dibandingkan dengan para pedagang, kecuali petani yang memasarkan produknya mengikuti rantai pemasaran "petani - penebas - pedagang pengumpul - bandar lokal" pada musim kemarau. Proporsi keuntungan petani untuk setiap rantai pasok bervariasi sangat besar yaitu berkisar antara $17,72 \%-56,04 \%$ dari seluruh keuntungan dalam rantai pasok bawang merah segar. Relatif masih rendahnya keuntungan yang diperoleh petani, salah satunya disebabkan oleh tingginya harga bibit. Sementara keuntungan terkecil diperoleh oleh penebas yang berkisar antara $16,42-26,22 \%$ dari total keuntungan semua pelaku yang terlibat. Walaupun keuntungan para pedagang lebih kecil dibandingkan dengan petani, namun tingginya perputaran siklus bisnis para pedagang dalam satu tahun memberikan akumulasi pendapatan yang lebih besar yang tercermin dari siklus bisnis bandar antar daerah pe 2 minggu, penebas hingga bandar lokal per bulan, sementara petani setahun paling banyak hanya 2 kali musim tanam. 


\section{Proporsi Nilai Tambah Pelaku Terhadap Nilai Tambah Total Rantai Pasokan Bawang Merah}

Aspek keadilan dalam rantai pasokan bawang merah segar dapat dilihat dari distribusi nilai tambah antar pelakunya. Hasil analisis menunjukkan bahwa nilai tambah terbesar dari total seluruh nilai tambah pelaku rantai pasok bawang merah di seluruh wilayah kajian adalah di petani $(29,85 \%$ - 64,40\%). Penerima nilai tambah selanjutnya adalah bandar antar daerah $(23,06 \%-38,73 \%)$, selanjutnya pedagang pengumpul dengan proporsi nilai tambah $18,86 \%$ - 29,21\% dan bandar besar lokal pemasok pasar induk $(18,45 \%-25,14 \%)$. Sedangkan yang terkecil adalah penebas $(17,15 \%-22,17 \%)$.

Dengan demikian, petani mendapatkan proporsi nilai tambah yang tertinggi dibandingkan dengan pelaku yang lain. Namun untuk melihat sejauh mana kepantasan atau adil tidaknya pelaku mendapatkan nilai tambah, tidak hanya semata-mata didasarkan kepada proporsi nilai tambah tetapi juga dibandingkan berdasarkan siklus produksi (siklus usaha), siklus aliran kas dan investasi yang dikeluarkan.

Mengacu kepada indikator tersebut di atas, maka sangatlah wajar dan adil apabila petani mendapatkan nilai tambah terbesar. Hal tersebut disebabkan nilai tambah petani diperolehnya dari aktifitas budidaya bawang merah yang banyak menggunakan tenaga kerja dan input internal serta membutuhkan waktu yang lama (60 - 90 hari) untuk satu kali siklus usahanya termasuk pengolahan lahan. Sementara dilihat dari aspek siklus aliran kas (waktu antara pengeluaran untuk biaya produksi dan penerimaan), hasil kajian menunjukkan bahwa siklus aliran kas petani terkait dengan siklus produksinya dan waktu yang dibutuhkan untuk menyediakan sarana produksi dan pembayaran dari penjualan hasil produksinya, ternyata pada umumnya petani membutuhkan waktu aliran kas antara 60-90 hari. Waktu aliran kas yang 60 hari adalah petani yang menjual dengan cara ijon. Selain itu, dalam satu tahun pada umumnya budidaya yang dilakukan maksimal hanya 2 kali siklus produksi, sehingga petani berhak dan sangat wajar mendapatkan imbalan kesejahteraan tertinggi (Gambar 11).

Sementara itu, lebih kecilnya nilai tambah yang diperoleh oleh pedagang dan penebas tidak mencerminkan lebih kecilnya keuntungan yang diterimanya dibandingkan petani. Pedagang dan penebas menerima proporsi nilai tambah lebih kecil, tetapi perputaran aliran kas jauh lebih cepat yaitu 0-15 hari sehingga hari kerja dalam setahun yang jauh lebih panjang mengakibatkan nilai atau omzet pedagang dan penebas menjadi lebih tinggi. Apalagi untuk bandar antar daerah dengan akumulasi pendapatan dari perputaran aliran kas dan tingginya volume bawang merah segar yang diperjualbelikan membuat keuntungan yang diterima dalam setahun menjadi jauh lebih tinggi dari pada petani, penebas atau pedagang bawang lainnya.

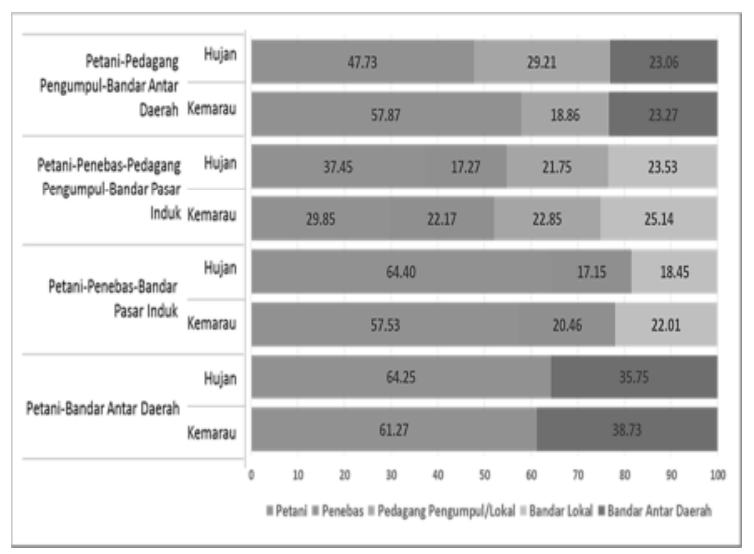

Gambar 11. Proporsi Nilai Tambah Pelaku Terhadap Total Nilai Tambah Rantai Pasokan

\section{KESIMPULAN}

Pola produksi bawang merah Provinsi Jawa Barat sangat dipengaruhi oleh 5 Kabupaten sentra produksi utama bawang merah. Pengaruh dari ke-5 kabupaten sentra produksi bawang merah tersebut disebabkan kontribusi/share kumulatif ke-5 kabupaten tersebut terhadap ketersediaan bawang merah Jawa Barat sangat besar yaitu 98,42\% dari total produksi Jawa Barat. Pola produksi bawang merah di Jawa Barat secara umum pada periode tahun 2009-2013, menunjukkan rata-rata produksi bawang merah tinggi terjadi pada bulan Januari, Februari dan Oktober sedangkan rata-rata produksi bawang merah terendah terjadi di bulan Desember dan juga penurunan produksi terjadi di bulan Juni, Juli dan Agustus.

Secara umum, distribusi bawang merah dari petani sampai dengan konsumen terbagi menjadi 3 yaitu: petani melalui penebas, petani melalui pedagang pengumpul dan petani menjual langsung bandar antar daerah. Penebas akan mendistribusikan sebagain besar bawang dari petani ke pedagang pengumpul, bandar lokal dan bandar antar daerah. Selanjutnya oleh bandar antar daerah disalurkan ke pasar induk Jabodetabek, pasar antar pulau dan ekspor. Sedangkan bandar lokal akan mendistribusi- 
kannya ke Pasar Induk caringin dan industri pengolahan makanan.

Jaringan pemasaran bawang merah Jawa Barat dipengaruhi oleh 1). preferensi konsumen yang cenderung lebih memilih bawang varietas Bima Brebes untuk dikonsumsi; 2). kondisi sosial budaya petani bawang di Jawa Barat terbiasa menanam bawang varietas Batu tuktuk dan maja yang lebih cocok digunakan sebagai bahan baku industri bawang goreng; dan 3). keberadaan pelaku yang memiliki akses pasar luar Jawa Barat.

Nilai tambah terbesar dari total seluruh nilai tambah pelaku rantai pasok bawang merah di seluruh wilayah kajian sebagai berikut: petani memiliki nilai tambah terbesar dengan proporsi nilai tambah sekitar $(29,85 \%$ $64,40 \%$ ). Penerima nilai tambah selanjutnya adalah bandar antar daerah yang mendapatkan proporsi nilai tambah sekitar $23,06 \%-38,73 \%$, selanjutnya pedagang pengumpul dengan proporsi nilai tambah sekitar 18,86\% - 29,21\% dan bandar besar lokal pemasok pasar induk $18,45 \%-25,14 \%$. Sementara yang terkecil adalah penebas sebesar $17,15 \%-22,17 \%$.

Namun besar dan kecilnya nilai tambah yang diperoleh oleh masinng-masing pelaku tidak mencerminkan nilai keuntungan yang diterimanya. Jika dilihat dari perputaran kas maka keuntungan terbesar masih diterima oleh bandar antar daerah, bandar lokal dan penebas. Petani membutuhkan waktu 60 - 90 hari kerja untuk mendapatkan keuntungan dari penanaman bawang sedangkan bandar dan penebas perputaran kasnya tiap saat atau 0-15 hari sehingga hari kerja bandar dan penebas lebih panjang dibandingkan petani dalam perputaran bawang sehingga nilai omzet pedagang dan penebas lebih tinggi.

Provinsi Jawa Barat merupakan salah satu sentra produksi bawang merah nasional, namun pada saat yang bersamaan juga merupakan provinsi dengan kebutuhan bawah merah terbesar di tingkat nasional. Permintaan yang sangat besar tersebut disebabkan Provinsi Jawa Barat merupakan provinsi dengan jumlah penduduk terbesar. Di lihat dari sisi produksi dan penawaran menunjukkan bahwa dalam 5 tahun terakhir produksinya relatif tidak berubah, sedangkan jumlah penduduknya meningkat terus. Keadaan ini menyebabkan Provinsi Jawa barat selalu defisit bawang merah walaupun produksi bawang merahnya merupakan provinsi penghasil bawang merah ketiga terbesar setalah Jawa Tengah dan Jawa Timur.

\section{DAFTAR PUSTAKA}

Amanor-Boadu V. 2005. A Conversation about Value-Added Agriculture. Value-Added Business Development Program, Department of Agricultural Economics, Kansas State University.

Bunte. 2006. Pricing and Performance Agri-Food Supply Chains in Proceedings of the Frontis Workshop on Quantifying the Agrifood Supply Chain,edited by Ondersteijn, Wijnands, Huirne, Kooten and Rogers. Netherlands.

Da Silva, Baker, Shepperd, Jenme and Miranda-da cruz. 2009. Agroindustries for Development. FAO of the UN and United Nations Industrial Development Organization with CAB Institutional. London UK.

Daniel Roduner, LBL. 2004. Report on Value Chain: Draft Analysis of Existing Theories, Methodologies and Discussions of Value Chain Approaches within The Development Cooperation Sector. Bern.

Derek Parker. et. al.,. 1992. Value Chain Handbook. Canada: Alberta Agriculture, Food and Rural Development.

GTZ Eschborn. 2007. ValueLinks Module 2. Kaplinsky, Raphael dan Mike Morris,2001. A Handbook For Value Chain Research.

Porter, Michael E. 1985. Competitive Advantage: Creating and Sustaining Superior Performance.

Schmitz, Hubert. 2001. Manual For Value Chain Research On Homeworkers In The Garment Industry. Institute of Development Studies.University of Sussex, Inggris. Schmitz, Hubert. 2005. Value Chain Analysis for Policy-Makers and Practitioners Institute of Development Studies. University of Sussex, Inggris.

Shank, John K dan Vijay Govindarajan. 1993. Strategic Cost Management and The Value Chain.

Van den Berg, Michael et.al. Making Value Chain Work Better For The Poor.A Toolbook for Practicioners of Value Chain Analysis. M4P

Vorley, Bill and Felicity Proctor. 2008. Inclusive Business in Agrifood Markets: Evidence and Action. A report based on proceedings of an international conference held in Beijing, March 5-6, 2008. Regoverning Market.

Webber and Labaste. 2010. Building Competitiveness in Africa's Agriculture. Agriculture and Rural Development. World Bank. Washington. 